\title{
A Study of the Final Stages of the Austenite to Martensite Transformation in SAE 1050 Steel $^{1}$
}

\author{
Melvin R. Meyerson and Samuel J. Rosenberg
}

\begin{abstract}
The austenite-martensite transformation curves in the temperature range from $\mathrm{M}_{\mathrm{s}}$ to $-320^{\circ} \mathrm{F}$ have been established for two SAE 1050 steels. No significant effect of austenitizing temperature or austenite grain size on the amount of martensite formed per degree drop in transformation temperature was observed at temperatures lower than about $100^{\circ} \mathrm{F}$ below the $M_{s}$. Within the limits tested, cooling rate from the austenitizing temperature had no effect on the austenite-martensite transformation. The amount of martensite formed per degree drop in temperature decreased at transformation temperatures of about $350^{\circ} \mathrm{F}$ and below, and the transformation did not go to completion even at the lowest temperature utilized $(-320 \mathrm{~F})$. At this temperature the amount of retained austenite was about 1 percent.
\end{abstract}

\section{Introduction}

The literature contains many references to investigations of the austenite-martensite reaction, particularly the temperature at the start of the transformation, the $\mathrm{M}_{\mathrm{s}}$. Considerably fewer studies have been concerned with the completion of the martensite transformation, the $\mathrm{M}_{\mathrm{f}}$. Among these are the studies of Cohen [1] ${ }^{2}$, Averbach and Cohen [2], Averbach, Castleman, and Cohen [3], Roberts [4], Lyman and Troiano [5], Harris and Cohen [6], Howard and Cohen [7], Grange and Stewart [8], and Sadovski and Bogacheva [9]. In most of the work reported by these authors, highly alloyed materials were used. Data on effects of such heat treating variables as austenitizing temperature and grain size on the $M_{1}$ of carbon steels are quite meager.

In a study [10] of the influence of austenitizing temperature, austenite grain size, and cooling rate on the martensite transformation in two SAE 1050 steels, the authors found that the $\mathrm{M}_{\mathrm{s}}$ was raised and that the initial quantities of martensite formed below the $\mathrm{M}_{\mathrm{s}}$ was decreased as the austenite grain size was increased. Austenitizing temperature had no effect on the $\mathrm{M}_{\mathrm{s}}$ except insofar as it established the austenite grain size. Cooling rate, within the limits studied, also had no effect. This study has been extended to ascertain the effects of these heat treating variables on the completion of the martensite transformation $\left(\mathrm{M}_{\mathrm{f}}\right)$.

\section{Materials and Experimental Procedures}

The same two steels that were used to study the effects of heat treating variables on the $\mathrm{M}_{\mathrm{s}}$ transformation were used for the present work. Their compositions, as given in table 1 , were similar except that M-182 had a greater aluminum content and was of "controlled" grain size whereas M-179 was not.

The quench-temper method as described previously [10] was used in this study. As before, the

1 This work was sponsored by Watertown Arsenal, Ordnance Corps, U. S. Army.

2 Figures in brackets indicate the literature references at the end of this paper. entire quench-temper cycle was limited to a maximum time interval of 11 sec in order to prevent the isothermal formation of bainite.

Specimens $(0.050$ in. $\times 0.10$ in. $\times 0.10$ in. $)$ were austenitized at $1,475^{\circ}$ and $1,600^{\circ} \mathrm{F}$ for $7 \mathrm{~min}$ and at $1,750^{\circ}, 1,900^{\circ}, 2,025^{\circ}$, and $2,150^{\circ} \mathrm{F}$ for $3 \mathrm{~min}$. The austenite grain sizes established under these conditions are shown in table 2. Those specimens transformed above room temperature were quenched for $3 \mathrm{sec}$ in 50 percent lead-50 percent bismuth alloy and then tempered for $8 \mathrm{sec}$ at $625^{\circ} \mathrm{F}$ in another pot containing the same alloy. The remainder were quenched to room temperature in water, to $19^{\circ} \mathrm{F}$ in iced brine, to $-105^{\circ} \mathrm{F}$ in a mixture of $\mathrm{CCl}_{4}+$ $\mathrm{CHCl}_{3}+$ solid $\mathrm{CO}_{2}$, and to $-320^{\circ} \mathrm{F}$ in liquid nitrogen. The approximate cooling rates of the small specimens in these media, as measured over the range $1,300^{\circ}$ to $900^{\circ} \mathrm{F}$ were: $\mathrm{Pb}-\mathrm{Bi} 5,000^{\circ} \mathrm{F} / \mathrm{sec}$, water $8,000^{\circ} \mathrm{F} / \mathrm{sec}$, iced brine $14,000^{\circ} \mathrm{F} / \mathrm{sec}, \mathrm{CCl}_{4}+$ $\mathrm{CHCl}_{3}+\mathrm{CO}_{2} 320^{\circ} \mathrm{F} / \mathrm{sec}$, and liquid nitrogen $190^{\circ}$ $\mathrm{F} / \mathrm{sec}$. Some of the specimens quenched directly to

TABLE 1. Chemical composition of the steels used Percentage by weight

\begin{tabular}{|c|c|c|c|c|c|c|c|c|c|c|c|}
\hline \multirow[b]{2}{*}{ Steel } & \multirow[b]{2}{*}{$\mathrm{C}$} & \multirow[b]{2}{*}{$\mathrm{Mn}$} & \multirow[b]{2}{*}{$\mathrm{P}$} & \multirow[b]{2}{*}{$\mathrm{S}$} & \multirow[b]{2}{*}{ Si } & \multirow[b]{2}{*}{$\begin{array}{l}\mathrm{Al}_{2} \\
\mathrm{O}_{3}\end{array}$} & \multicolumn{2}{|c|}{$\mathrm{Al}$} & \multirow[b]{2}{*}{$\mathrm{H}$} & \multirow[b]{2}{*}{$\mathrm{O}$} & \multirow[b]{2}{*}{$\mathrm{N}$} \\
\hline & & & & & & & $\begin{array}{c}\text { Acid } \\
\text { solu- } \\
\text { ble }\end{array}$ & Total & & & \\
\hline $\begin{array}{l}\text { M-179 } \\
\text { M-182 }\end{array}$ & $\begin{array}{l}0.49 \\
0.49\end{array}$ & $\begin{array}{l}0.79 \\
0.80\end{array}$ & $\begin{array}{l}0.023 \\
0.022\end{array}$ & $\begin{array}{l}0.023 \\
0.028\end{array}$ & $\begin{array}{l}0.22 \\
0.21\end{array}$ & $\begin{array}{l}0.001 \\
0.007\end{array}$ & $\begin{array}{l}0.002 \\
0.016\end{array}$ & $\begin{array}{l}0.003 \\
0.020\end{array}$ & $\begin{array}{l}0.0002 \\
0.0002\end{array}$ & $\begin{array}{l}0.004 \\
0.003\end{array}$ & $\begin{array}{l}0.004 \\
0.004\end{array}$ \\
\hline & 0.73 & 0.00 & & 0.020 & 0.21 & 0.000 & 0.010 & 0.02010 & 0.0002 & 0.000 & 0.007 \\
\hline
\end{tabular}

TABLE 2. Effect of austenitizing conditions on grain size

\begin{tabular}{|c|c|c|c|}
\hline \multicolumn{2}{|c|}{ Austenitizing } & \multicolumn{2}{|c|}{$\begin{array}{l}\text { ASTM grain size } \\
\text { number }\end{array}$} \\
\hline $\begin{array}{l}\text { Temper- } \\
\text { ature }\end{array}$ & Time & M-179 & M-182 \\
\hline $\begin{array}{c}{ }^{\circ} \mathrm{F} \\
1,475 \\
1,600 \\
1,750 \\
1,900 \\
2,025 \\
2,150\end{array}$ & $\begin{array}{c}\min \\
7 \\
7 \\
3 \\
3 \\
3 \\
3\end{array}$ & $\begin{array}{c}8 \\
5 \\
4-5 \\
4 \\
3 \\
2\end{array}$ & $\begin{array}{c}8 \\
7-8 \\
5 \\
5 \\
5 \\
3\end{array}$ \\
\hline
\end{tabular}


$-320^{\circ} \mathrm{F}$ in liquid nitrogen contained appreciable amounts of pearlite due to the slow cooling rate of the medium. This was particularly true of the finegrained steel $(\mathrm{M}-182)$ austenitized at $1,475^{\circ} \mathrm{F}$. Therefore, some specimens were quenched to $-320^{\circ}$ $\mathrm{F}$ indirectly, with an intermediate quench of $6 \mathrm{sec}$ in either iced brine or $\mathrm{CCl}_{4}+\mathrm{CHCl}_{3}+$ solid $\mathrm{CO}_{2}$. This procedure also afforded an opportunity to observe any effect of the short delay in quenching on the $\mathrm{M}_{\mathrm{f}}$; i. e., any stabilizing effect. Specimens quenched directly to $-320^{\circ} \mathrm{F}$ and which contained as much as one-half percent of pearlite were discarded.

An Einthoven string galvanometer, actuated by a thermocouple welded to the specimen, served to determine the temperature reached by the specimen just prior to tempering. This instrument was not used in conjunction with specimens quenched to room temperature or lower.

After mounting, all specimens were carefully ground to midpoint and given a metallographic po]ish. Lineal analysis was employed to determine the amount of tempered martensite up to about 90 percent. When more than this was present, the light constituents (austenite plus fresh martensite) were too finely dispersed to permit accurate lineal analysis. Typical microstructures showing advanced stages of the austenite-martensite transformation are shown in figure 1. In order to determine the amount of austenite in specimens containing more than about 90 percent of martensite, X-ray diffraction techniques, similar to the integrated intensity method reported by Averbach and Cohen [2] were used. A modification in computation described by Beu [11] was found to agree closely with the longer procedure of Averbach and Cohen and gave comparable results with less calculation. It was used throughout, with occasional verification by the longer method.

X-ray exposures were for $24 \mathrm{hr}$, using Co $\mathrm{K} \alpha$ radiation. A monochrometer equipped with a pentaerythritol crystal was employed to reduce back- ground; this crystal had a $2 \theta$ angle of $23.60^{\circ}$ when used with Co $\mathrm{K} \alpha$ radiation. Since X-ray methods could not be applied to specimens transformed at temperatures above ambient (subsequent cooling to room temperature would cause the transformation of some of the untransformed austenite) and since lineal analysis could not be used on specimens that had formed more than about 90 percent of martensite, no determinations could be made in this range (approximately room temperature to about $350^{\circ} \mathrm{F}$ ). Consequently, all graphs of percent martensite versus transformation temperature plotted from experimental data have no points located in this range. The effect on the shape of the transformation curves (percent martensite versus transformation temperature) was negligible, since the quantity of austenite transformed with decreasing temperatures was extremely small both at temperatures just above and below this range.

A conventional powder camera of $57.3-\mathrm{mm}$ diam was modified to accommodate the mounted specimens. The specimen holder was redesigned so as to allow the specimen to rotate slowly in the plane of its surface. By so doing the diffraction lines were uniformly free from spottiness except for specimens of steel M-179 austenitized at $2,150^{\circ} \mathrm{F}$. The influence of the large grains in this steel (ASTM No. 2 ) in causing spottiness could not be eliminated by rotation. Details of the modified camera are shown in figures 2 and 3 . The amount of light transmitted through the austenite and martensite lines on the X-ray film was determined by means of a recording microphotometer. From these data the density of the blackening curves was constructed on lineal scales and the areas under the peaks measured with a planimeter. The relative areas were used to compute the amounts of austenite and martensite. The film used was tested for linearity of blackening as a function of the amount of exposure and was found to be linear in the ranges used.
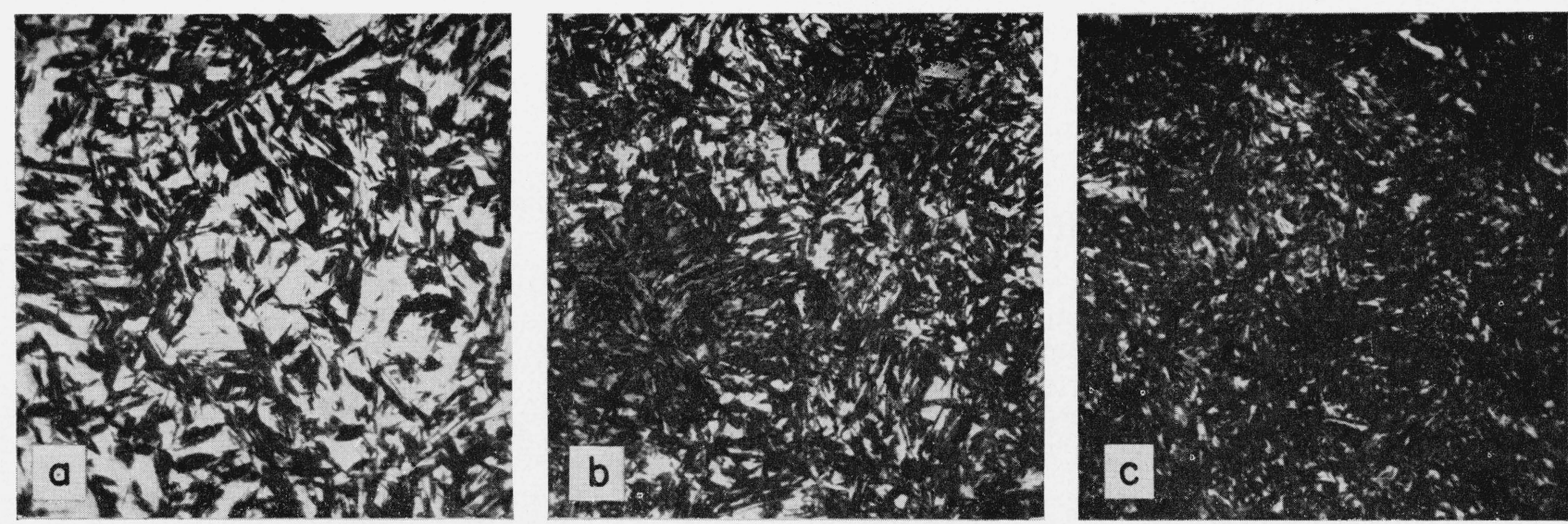

FIGURE 1. Typical microstructures showing advanced stages of the austenite-martensite transformation.

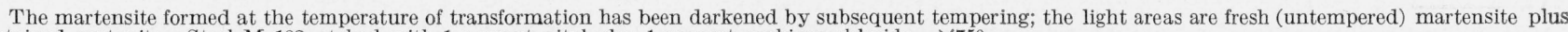
retained austenite. Steel M-182, etched with 1 percent nital plus 1 percent zephiran chloride. $\times 750$.

a, Transformed at $510^{\circ} \mathrm{F}, 62 \%$ martensite; b, transformed at $465^{\circ} \mathrm{F}, 81 \%$ martensite; c, transformed at $410^{\circ} \mathrm{F}, 93 \%$ martensite lineal analysis of structures of this type are difficult. It represents the approximate limit for which lineal analysis was used. 


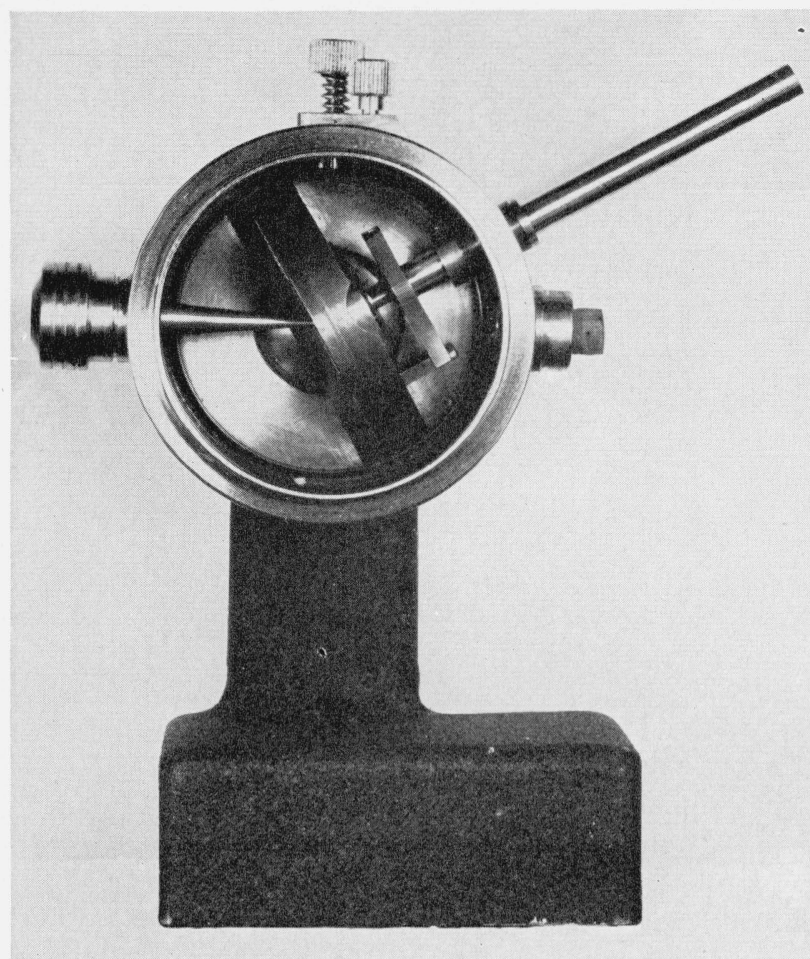

Figure 2. Modified X-ray camera, assembled view with cover removed.

$\times$ approx. $1 / 2$

\section{Results}

The amount of martensite formed upon quenching to different temperature levels below $\mathrm{M}_{\mathrm{s}}$ and down to $-310^{\circ} \mathrm{F}$ was determined experimentally and then plotted to obtain transformation curves similar to the typical curves shown in figure 4. A complete curve, as illustrated, was obtained for each steel and for each austenitizing condition. It was reported previously [10], when only the initial portion of the curves was available, that those curves having lesser initial slopes (corresponding to the formation of smaller amounts of martensite per degree drop in temperature) showed tendencies to change towards increased slopes (corresponding to the formation of larger amounts of martensite per degree drop in temperature) with further decreases in transformation temperature. This trend now has been definitely established and is illustrated by the curves in figure 4 . The initial slope of each curve increases to a constant value that is maintained until about 70 percent transformation has occurred.

The martensite-transformation temperature curves for each steel and for every austenitizing condition (only two of these curves are shown in fig. 4) contain values obtained on quenching directly as well as indirectly to $-320^{\circ} \mathrm{F}$. With one exception (steel M-179 austenitized at $1,750^{\circ} \mathrm{F}$ ) all quantities of martensite obtained by indirect quench were within 1 percent of those obtained by direct quench.

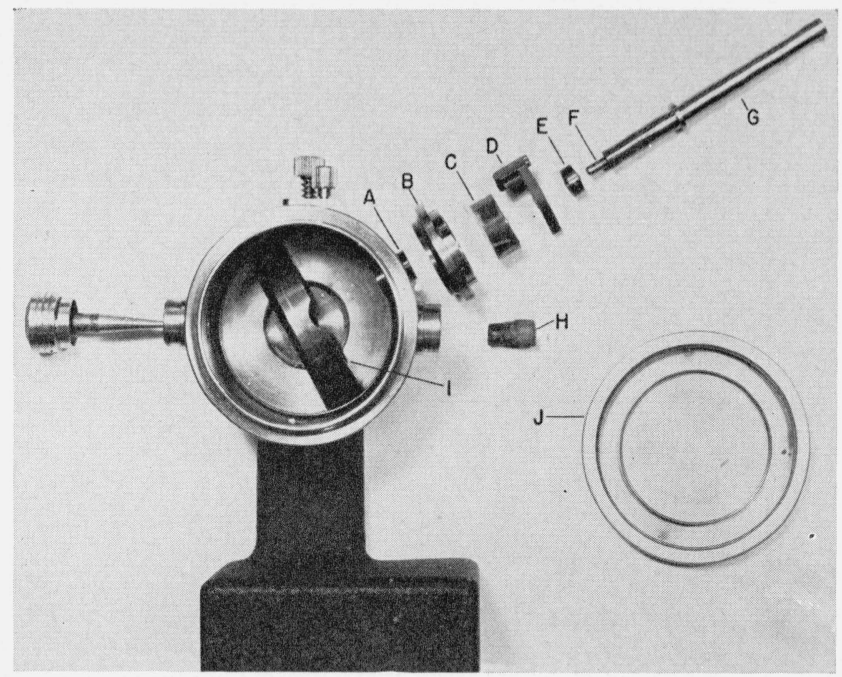

Figure 3. Modified X-ray camera, exploded view. $\times 1 / 3$.

A, Bearing for drive shaft; B, rotating specimen holder; $\mathrm{C}$, specimen in plastic mount; D, crank; E, locking collar; F, spring-loaded plunger; G, rotating drive shaft; H, stopper; I, bearing for specimen holder; J, light-tight cover.

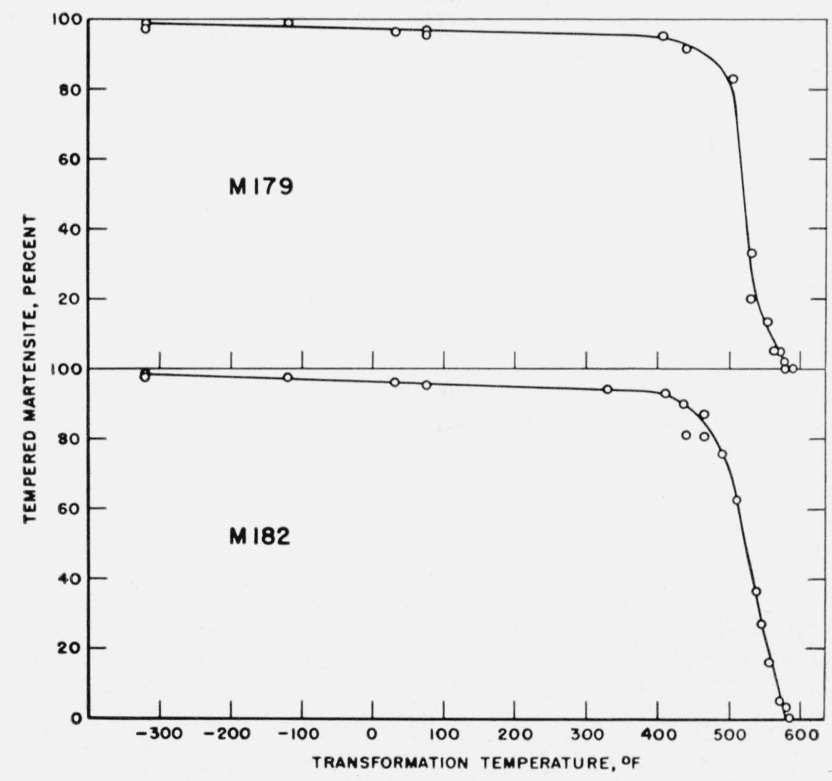

Figure 4. Transformation curves for the steels austenitized at $1,475^{\circ} \mathrm{F}$.

These data indicated no effect of stabilization due to the short interruption of quench.

The amount of martensite for both steels transformed in the range of +100 to $-320^{\circ} \mathrm{F}$ was approximately the same at any single temperature of transformation, regardless of the austenitizing temperature. The amount of martensite formed at $-320^{\circ} \mathrm{F}$ was $98 \pm 1$ percent. This was found to be true for both steels and for every austenitizing temperature used. 


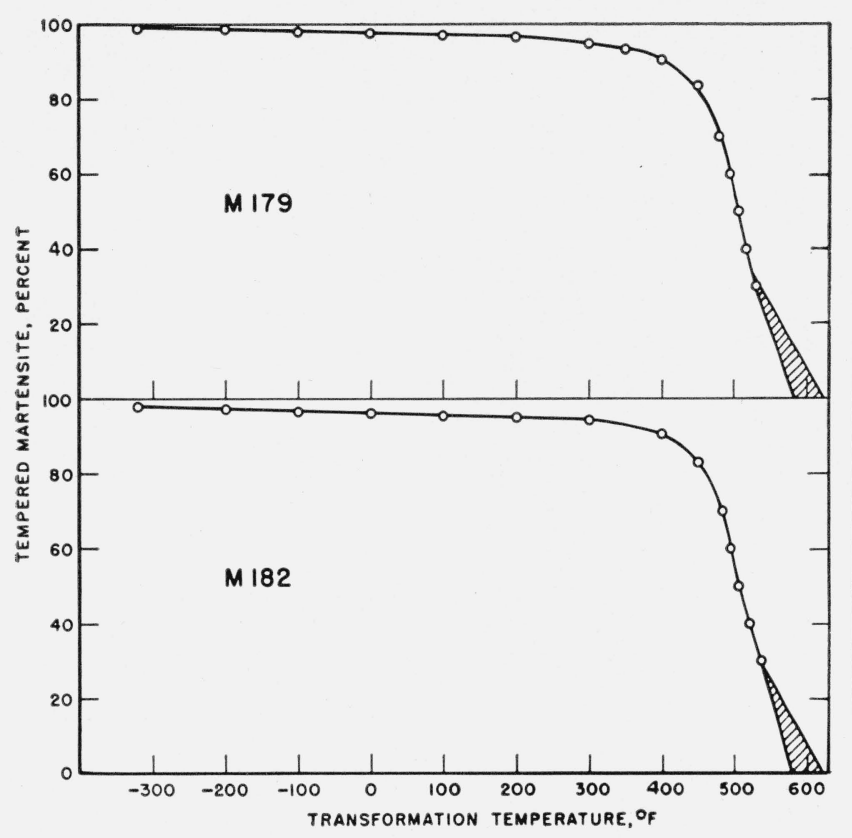

Figure 5. Consolidated transformation curves for the steels austenitized at temperatures ranging from $1,475^{\circ}$ to $2,025^{\circ} \mathrm{F}$. for steel $M-179$ and from $1,475^{\circ}$ to $2,150^{\circ} \mathrm{F}$. for steel $M-182$.

Figure 5 shows the consolidated curve for each steel under all austenitizing conditions. These curves are very similar and were derived as follows: In the range $\mathrm{M}_{\mathrm{s}}$ to about $\mathrm{M}_{\mathrm{s}}-100^{\circ} \mathrm{F}$, values were taken from a previous paper [10]. The shaded area in each curve represents the spread in slope and the variations in $\mathrm{M}_{8}$ obtained in these steels with the different grain sizes established by the range of austenitizing temperatures. In the range of transformation temperatures of $\mathrm{M}_{\mathrm{s}}-100^{\circ} \mathrm{F}$ to approximately $300^{\circ} \mathrm{F}$ the transformation temperatures at which regular 10 percent increases of martensite were formed were determined from the individual transformation curves and averages. The spread in values between the different curves was small enough to justify this procedure. These averages were then plotted in figure 5 as a function of martensite formed. In the range of transformation temperatures of $300^{\circ}$ to $-320^{\circ} \mathrm{F}$ the martensite formed at regular increments of $100^{\circ} \mathrm{F}$ and at $-320^{\circ} \mathrm{F}$ was determined from the individual transformation curves (two of these curves are shown in fig. 4) for each steel and for every austenitizing condition. These data are shown in table 3 and the averages for each transformation temperature are shown in the last column of that table. The averages were then plotted in figure 5 as a function of transformation temperature.

On the basis of these curves and the data in table 3 it was concluded, that for the steels studied, variations in austenitizing temperature and grain size did not influence the quantities of austenite transformed to martensite at temperatures lower than about $100^{\circ} \mathrm{F}$ below the $\mathrm{M}_{\mathrm{s}}$. Furthermore, variations in cooling rate over the range investigated made no difference in the amount of austenite retained at $-320^{\circ} \mathrm{F}$.
TABLE 3. Duantity of martensite formed as a function of transformation and austenitizing temperatures

\begin{tabular}{|c|c|c|c|c|c|c|c|}
\hline \multirow{2}{*}{$\begin{array}{l}\text { Trans- } \\
\text { for- } \\
\text { mation } \\
\text { temper- } \\
\text { ature } \\
\circ \mathrm{F}\end{array}$} & \multicolumn{6}{|c|}{$\begin{array}{c}\text { Percent of martensite at indicated transformation tem- } \\
\text { perature after austenitizing at- }\end{array}$} & \multirow{2}{*}{$\begin{array}{c}\text { A ver- } \\
\text { age } \\
\text { marten- } \\
\text { site, } \\
\%\end{array}$} \\
\hline & $1,475^{\circ} \mathrm{F}$ & $1,600^{\circ} \mathrm{F}$ & $1,750^{\circ} \mathrm{F}$ & $1,900^{\circ} \mathrm{F}$ & $2,025^{\circ} \mathrm{F}$ & $2,150^{\circ} \mathrm{F}$ & \\
\hline \multicolumn{8}{|c|}{ Steel M-179 } \\
\hline $\begin{array}{r}300 \\
200 \\
100 \\
0 \\
-100 \\
-200 \\
-320\end{array}$ & $\begin{array}{l}96.1 \\
96.5 \\
97.0 \\
97.3 \\
97.7 \\
98.1 \\
98.4\end{array}$ & $\begin{array}{l}91.8 \\
94.6 \\
96.4 \\
97.7 \\
98.5 \\
99.0 \\
99.4\end{array}$ & $\begin{array}{l}96.0 \\
96.4 \\
96.8 \\
97.1 \\
97.4 \\
97.8 \\
98.0\end{array}$ & $\begin{array}{l}96.3 \\
97.1 \\
97.3 \\
97.4 \\
97.5 \\
97.6 \\
97.8\end{array}$ & $\begin{array}{l}93.7 \\
95.8 \\
97.3 \\
98.6 \\
99.0 \\
-.-- \\
--.\end{array}$ & 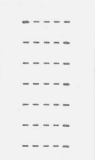 & $\begin{array}{l}94.8 \\
96.1 \\
97.0 \\
97.6 \\
98.0 \\
98.1 \\
98.4\end{array}$ \\
\hline \multicolumn{8}{|c|}{ Steel M-182 } \\
\hline $\begin{array}{r}300 \\
200 \\
100 \\
0 \\
-100 \\
-200 \\
-320\end{array}$ & $\begin{array}{l}94.3 \\
95.0 \\
95.6 \\
96.3 \\
97.0 \\
97.7 \\
98.3\end{array}$ & $\begin{array}{l}96.6 \\
97.0 \\
97.3 \\
97.6 \\
97.9 \\
98.3 \\
99.0\end{array}$ & $\begin{array}{l}93.8 \\
95.0 \\
96.0 \\
97.0 \\
97.8 \\
98.4 \\
99.0\end{array}$ & $\begin{array}{l}94.9 \\
95.6 \\
96.2 \\
97.0 \\
97.6 \\
98.2 \\
99.0\end{array}$ & $\begin{array}{l}94.5 \\
94.8 \\
95.2 \\
95.7 \\
96.1 \\
96.6 \\
97.0\end{array}$ & $\begin{array}{l}92.7 \\
94.0 \\
94.8 \\
95.5 \\
96.3 \\
97.1 \\
98.0\end{array}$ & $\begin{array}{l}94.5 \\
95.2 \\
95.9 \\
96.5 \\
97.1 \\
97.7 \\
98.4\end{array}$ \\
\hline
\end{tabular}

The term $\mathrm{M}_{\mathrm{f}}$ is generally considered as the temperature of the finish of the martensite transformation. It also has been defined as the temperature at which a certain large quantity of martensite, such as 95 or 98 percent, has formed. Neither of these definitions could be applied to the data obtained in this study to obtain a definite $\mathrm{M}_{\mathrm{f}}$. From the transformation curves shown in figure 4 it can be seen that transformation was not complete even at temperatures as low as $-320^{\circ} \mathrm{F}$, and the slopes of the curves in the region of 95 to 99 percent martensite were so low that the intersections of these curves with the abscissas (temperature scale) could not be determined with any degree of accuracy. Consequently, it was not possible to pinpoint any specific temperature as the $\mathrm{M}_{\mathrm{f}}$ of either steel.

\section{Discussion}

The reaction-path theory advanced by Cohen, Machlin, and Paranjpe [12] postulates that the difference in the chemical free energy of austenite $\left(\mathrm{F}^{\mathrm{A}}\right)$ minus that of martensite $\left(\mathrm{F}^{\mathrm{M}}\right)$ must be greater than the resisting energies of dilatation, interfaces, and coherencies in order for the martensite reaction to proceed. Large grains lower the resisting energies because of decreased interfaces and permit the reaction to occur at lower values of $\mathrm{F}^{\mathrm{A}}-\mathrm{F}^{\mathrm{M}}$, thus accounting for the higher $\mathrm{M}_{\mathrm{s}}$ with coarse-grained austenite.

As has been explained previously [10], the amount of martensite formed per degree drop in transformation temperature just below the $M_{s}$ is less with coarse-grained than with fine-grained austenite. However, after about 30 percent of martensite has formed, at a temperature approximately $100^{\circ} \mathrm{F}$ below $\mathrm{M}_{\mathrm{s}}$, the influence of the initial grain size disappears. This was explained by the fact that the effective austenite grain size has been reduced by the martensite platelets to such an extent that the resisting energies of the interfaces have been raised to 
equal those of the initially finer-grained austenite. With further reduction of transformation temperature, therefore, essentially similar amounts of transformation are obtained regardless of the initial austenite grain size.

Cohen [1] has presented an equation whereby the $\mathrm{M}_{\mathrm{s}}$, the quantity of martensite formed, or the temperature of transformation of the quantity of martensite $\left(\mathrm{T}_{\mathrm{q}}\right)$ can be computed if any 2 of the 3 variables are known. This formula is: $\%$ Martensite $=100 \times$ $3.05 \times 10^{-14} \quad\left[820-\left(\mathrm{M}_{\mathrm{s}}-\mathrm{T}_{\mathrm{q}}\right)\right]^{5.32}$, where $\mathrm{T}_{\mathrm{q}}$ is the temperature of quench in ${ }^{\circ} \mathrm{F}$. The types of steels to which this formula was said to be applicable did not include the 0.50 percent carbon steels under investigation. When applied to the steels under study, this formula gave a reasonably close approximation to the experimental transformation curves up to about 95 percent of martensite. However, the formula does not contain provision for variation of $\mathrm{M}_{\mathrm{s}}$ with austenite grain size and any $\mathrm{M}_{\mathrm{s}}$ obtained with it will hold only for a single grain size.

\section{Summary and Conclusions}

1. The austenite-martensite transformation curves in the temperature range from $\mathrm{M}_{\mathrm{s}}$ to $-320^{\circ} \mathrm{F}$ have been established for two SAE 1050 steels. No significant effect of austenitizing temperature or austenite grain size on the amount of martensite formed per degree drop in transformation temperature was observed at transformation temperatures lower than about $100^{\circ} \mathrm{F}$ below the $\mathrm{M}_{\mathrm{s}}$. Within the limits tested, cooling rate from the austenitizing temperature had no effect on the austenite-martensite transformation. No stabilizing effect could be determined as the result of briefly interrupting the quench to $-320^{\circ} \mathrm{F}$. Because of the fact that the transformation curves became asymptotic to the temperature axis and because some traces of austenite were present in the steels even after transformation at temperatures as low as $-320^{\circ} \mathrm{F}$, it was not possible to pinpoint the $\mathrm{M}_{\mathrm{f}}$ temperatures.

2. The transformation curves for both steels were very similar, regardless of austenitizing temperatures, and fitted an empirical equation.
3. The reaction path theory accounts for the similarity of the austenite-martensite transformation curves of the two steels at the lower transformation temperatures as well as the differences in $\mathbf{M}_{9}$ obtained with changes in austenite grain size as previously reported [10].

The authors are grateful to Thomas G. Digges for many constructive suggestions and criticisms, to John F. Kocis for his conscientious assistance during the investigation, and to Herbert C. Vacher for his suggestions in the modification of the X-ray camera.

\section{References}

[1] M. Cohen, Retained austenite, Trans. ASM 41, 35 (1949).

[2] B. L. Averbach and M. Cohen, X-ray determination of retained austinite by integrated intensities, Trans. AIME 176, 401 (1948).

[3] B. L. Averbach, L. S. Castleman, and M. Cohen, Measurement of retained austenite in carbon steels, Trans. ASM 42, 112 (1950).

[4] C. S. Roberts, Effect of carbon on the volume fractions and lattice parameters of retained austenite and martensite, Trans. AIME 197, 203 (1953).

[5] T. Lyman and A. R. Troiano, Influence of carbon content upon the transformations in 3 percent chromium steel, Trans. ASM 37, 402 (1946).

[6] W. J. Harris, Jr. and M. Cohen, Stabilization of the austenite martensite transformation, Trans. AIME 180, $447(1949)$

[7] R. T. Howard, Jr. and M. Cohen, Austenite transformation above and within the martensite range, Trans. AIME 1\%6, 384 (1948).

[8] R. A. Grange and H. M. Stewart, The temperature range of the martensite formation, Trans. AIME, 167, 467 (1946)

[9] V. D. Sadovskii and G. N. Bogacheva, On the influence of the quenching temperature upon the quantity of retained austenite in steel, Doklady Akad. Nauk SSSR [2] 83, $221(1952)$

[10] M. R. Meyerson and S. J. Rosenberg, The influence of heat treating variables on the martensite transformation in SAE 1050 steel, Trans. ASM 46, 1225 (1954).

[11] K. E. Beu, Modifications of an X-ray method for the measurement of retained austenite concentrations in hardened steels, J. Metals 4, 1327 (1952).

[12] M. Cohen, E. S. Machlin, and V. G. Paranjpe, Thermodynamies of the martensite transformation, thermodynamics in physical metallurgy, ASM 242 (1950).

Washington, April 15, 1955 